\title{
Effects of Gamma Irradiation on the Shelf-life of a Dairy-like Product
}

by Odueke, O.B., Chadd, S.A., Baines, R.N., Farag, K.W. and Jansson, J.

Copyright, Publisher and Additional Information: This is the author accepted manuscript. The final published version (version of record) is available online via Elsevier

Please refer to any applicable terms of use of the publisher.

DOI: https://doi.org/10.1016/j.radphyschem.2017.09.013

$\mathbf{H}$ Harper Adams University

Odueke, O.B., Chadd, S.A., Baines, R.N., Farag, K.W. and Jansson, J. 2017. Effects of Gamma Irradiation on the Shelf-life of a Dairy-like Product. Radiation Physics and Chemistry. 


\section{Author's Accepted Manuscript}

Effects of Gamma Irradiation on the Shelf-life of a Dairy-like Product

Oluwakemi. B. Odueke, Stephen. A. Chadd, Richard. N. Baines, Karim. W. Farag, Jonathan Jansson

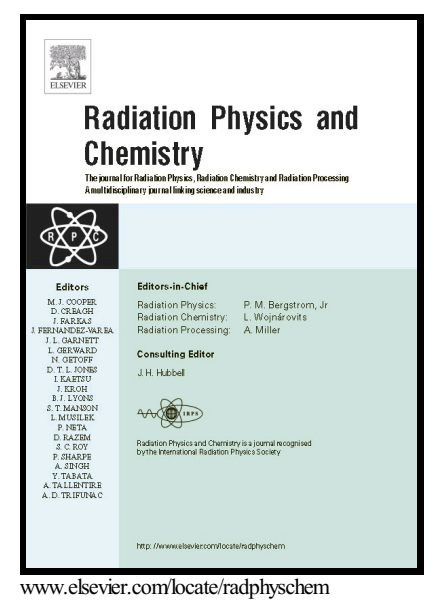

PII: $\quad$ S0969-806X(17)30263-3

DOI: $\quad$ http://dx.doi.org/10.1016/j.radphyschem.2017.09.013

Reference: RPC7646

To appear in: Radiation Physics and Chemistry

Received date: 28 February 2017

Revised date: 28 June 2017

Accepted date: 11 September 2017

Cite this article as: Oluwakemi. B. Odueke, Stephen. A. Chadd, Richard. N. Baines, Karim. W. Farag and Jonathan Jansson, Effects of Gamma Irradiation on the Shelf-life of a Dairy-like Product, Radiation Physics and Chemistry, http://dx.doi.org/10.1016/j.radphyschem.2017.09.013

This is a PDF file of an unedited manuscript that has been accepted for publication. As a service to our customers we are providing this early version of the manuscript. The manuscript will undergo copyediting, typesetting, and review of the resulting galley proof before it is published in its final citable form. Please note that during the production process errors may be discovered which could affect the content, and all legal disclaimers that apply to the journal pertain. 


\section{Effects of Gamma Irradiation on the Shelf-life of a Dairy-like Product}

Oluwakemi. B. Odueke ${ }^{1}$, Stephen. A. Chadd ${ }^{1}$, Richard. N. Baines ${ }^{1}$, Karim. W. Farag ${ }^{2}$, Jonathan. Jansson ${ }^{3}$.

${ }^{1}$ School of Agriculture, Food and Environment, Royal Agricultural University, Cirencester, UK.

${ }^{2}$ Department of Food Science and Agri-Food Supply Chain Management, Harper Adams University, Newport, UK

${ }^{3}$ STERIS Applied Sterilization Technologies, 1880 Industrial Drive, Libertyville, IL 60048, USA.

Corresponding Author:

Karim. W. Farag.

Department of Food Science and Agri-Food Supply Chain Management, Harper Adams University, Newport, UK

Email: kfarag@harper-adams.ac.uk

Tel:

Journal Name: Radiation Physics and Chemistry 


\section{Abstract}

This study was aimed to assess the effect of irradiation on the shelf-life of pseudo-dairy food product consisting of different concentration levels of the structural and energy-giving caloric component macronutrients (protein, fat and carbohydrate). Gamma irradiated products (1kGy, 3kGy, 5kGy and 10kGy) were compared to the current procedure used by the industry of non-irradiated dairy products. The study looked at the impact of different treatments on storage quality in respect to physicochemical ( $\mathrm{pH}$, acidity, macronutrients), and microbiological properties [total viable count (TVC)]. The products were aseptically packaged in plastic containers and analysed at regular weekly intervals up until 100 days during refrigerated storage at $4 \pm 1^{\circ} \mathrm{C}$. The storage period did not bring about any significant change in physicochemical properties of the products throughout the period of study while the TVC displayed a linear regression for irradiated products stored at $4 \pm 1^{\circ} \mathrm{C}$ as well as the control (non-irradiated). At the end of the shelf-life trial (benchmarked at log $4.3 \mathrm{CFU} / \mathrm{g}$ ), the total viable count did not exceed $\log 3.94 \mathrm{CFU} / \mathrm{g}$ for samples treated at $10 \mathrm{kGy}$ after 100 days of analysis. These observations indicated that the product could be safely stored aerobically for $>100$ days (10 and 5kGy), 56days at (3kGy), 42 days at (1kGy) for the irradiated samples and 14 - 28 days for the non-irradiated samples without much change in physicochemical and microbiological properties using refrigerated storage.

\section{Keywords}

Irradiation, Gamma irradiation, Shelf-life, Food technology, Food preservation, Dairy products 


\section{Introduction}

The safety and security of consumable food constitute a global concern which requires urgent attention along the supply chain from governments, multinational companies, processors and producers. In addition, scientists need to play an active role in addressing the problems of growing populations and food shortages (WHO, 1992). At the same time, the demand for safe, shelf-stable and additive-free foods, with optimal organoleptic and nutritional attributes has driven the emergence of novel food processing technology (Zink, 1997). It is important when improving food safety and product shelf-life, to also preserve the nutritional and sensorial quality (McClements et al., 2001; Ortega-Rivas, 2007). Over the years, several food preservation techniques have been used, adopted and accepted by the industries and consumers including: curing, smoking, salting, drying, and pasteurisation. These techniques, aside from eliminating food spoilage microorganism, often have limitations associated with them, especially modification to the organoleptic properties of the food. Non-thermal technologies are being used in food processing environment as a viable alternative to thermal processing, due to their capability to preserve food quality attributes (Farag et al., 2008; Farag et al., 2011). Given these interests, the application of novel non-thermal preservation techniques e.g. high-pressure processing, cold plasma and radiation technology, were researched and adopted by the food industry for processing many food categories (San Martin et al., 2002).

Irradiation as a food preservation technology is widely used in some countries such as the USA, France and South Africa, while in some countries like the UK and Germany, there is strong opposition (IFST, 2015). In those countries where there is resistance to the technology, the reasons given are varied and multi-dimensional hence, further research is needed. 


\section{ACCEPTED MANUSCRIPT}

In recent years, research into the future of food conservation has included studies into preservation techniques that will make food fresher, safer, healthy, and sustainable. There has also been a focus on technology, which will deliver environmental benefits such as the application of chemical-free processes, the reduction in the use of energy for cold transportation and storage, and reduction in the water consumption in the production line (Maherani, et al., 2016; Yun et al., 2012).

Irradiation is a novel, non-thermal processing technology for food. Hence, radiation processing, is the use of ionising radiation (gamma rays, electron beams or x-rays), to cause changes in cells, destroy microorganisms, or to achieve chemical modifications in materials (Crawford and Ruff., 1996). The ionising radiations are obtained from either radioisotope (Cobalt-60 sources, Cesium-137), or machine enabled (x-rays or electron beam) (EFSA, 2011; Huo et al., 2013). As documented by the EFSA, (2011), radiation processing has a wide-spectrum of activity proven to cause no toxicological or nutritional concerns in foods. In industrial processing, it induces desired chemical changes without the use of chemical catalysts, hence, it is environmentally-friendly in nature. As a technology, food irradiation, has been recommended by reputable international organisations such as Food and Agriculture Organisation (FAO), World Health Organisation (WHO) and the International Atomic Energy Agency (IAEA). The major areas of applications of radiation processing are irradiation of certain foods; medical sterilisation; industrial processing and environmental remediation (EFSA, 2011).

However, it is worth emphasising, that irradiated foods, are not radioactive due to the absorbed energy not being powerful enough to affect the neutrons in the nuclei of the food molecules (Mahapatra, 2005). Decades of research has documented food irradiation as a food safety technology with the capability to, eliminate food-borne pathogen and control spoilage by: inhibiting sprouting in crops such as onions and potatoes; delaying ripening of fresh fruits 


\section{ACCEPTED MANUSCRIPT}

and vegetables; as well as destroying insects and parasites in grains, dried fruits and vegetables, meat and seafood (Lacroix and Follett, 2015). Findings confirmed food irradiation as a technology with the capability of inactivating microorganisms without significantly affecting the sensory or other organoleptic characteristics of the food product (Khattak and Rahman, 2016). These reductions in the spoilage microorganisms account for the shelf-life extension in food, while, also potentially reducing the incidence of foodborne illness (Kume et al., 2009).

Irradiation is also used for; feed decontamination and provision of neutropenic diets for immuno-compromised patients requiring sterile foods (Kilcast, 1994; Pryke and Taylor, 1995). The efficiency of irradiation application on food commodities as a form of quarantine measure and post-harvest control has been reported (Burditt, 1994; Hallman, 2001; Lee, 2004); these include insect infestation inhibition through disruption to the breeding cycle, delays in ripening of fruits and sprouting inhibition. However, despite the documented benefits of radiation technologies, its transfer from research and development institutions to industry, especially through commercialisation, remains a challenging task. There is still a negative perception attached to the use of ionising radiation for processing food, thus significantly slowing the growth of the technology (Maherani et al., 2016).

\subsection{Previous studies on food irradiation}

Research spanning over 100 years has been conducted and widely documented on the beneficial effect of radiation technology in the reduction of bacteria, insect disinfestation and the enhancement of food shelf-life (Komolprasert, 2007). According to Lacroix and Ouattara (2000), doses within the range of 0.25 and $2.25 \mathrm{kGy}$ are sufficient for extending the shelf-life of fruit and vegetable without significant change in quality such as the sensorial properties, accelerated ripening, loss of firmness and physiological breakage. Studies by Adiel Pietranera et al., 2003 irradiated ice creams at different doses revealed that a dose of $3 \mathrm{kGy}$ is sufficient 


\section{ACCEPTED MANUSCRIPT}

in achieving a $10^{3}$ reduction in total bacteria count and $10^{2}$ reduction in yeasts and moulds, while also inactivating Staphylococcus spp. and total coliforms thereby attaining an acceptable microbiological condition for diets of the immunocompromised. Studies on cheese also reported the potential use of irradiation for controlling food borne diseases and extending the shelf-life without any considerable effect on the nutritional and sensorial properties (Blank et al., 1992; Lalaguna, 2003; Bougle and Stahl, 1994; Tsiotsias et al., 2002). However, regardless of the reported studies, further research are required on the effect of gamma irradiation on dairy products due to scarce literature when compared to other product of animal origin.

\subsection{Study aim}

This study set out to investigate the use, ability and suitability of gamma radiation as a technological process, with emphasis on the microbial safety and quality of a pseudo-dairy product (Kemi block). This experiment, was design as a preliminary investigation which, will subsequently be used as a protocol for standardising future experiments on dairy products based on, the radiation source, dose, macronutrient and temperature while giving consideration to the practicality of the technology.

\section{Materials and method}

\subsection{Production of Kemi block}

Kemi block is analogous to a dairy product. Six different compositions were created to mimic and simulate different groups of dairy-like products. These were high and low protein; high and low fat; and high and low carbohydrate denoting different food products in the dairy food groups with differing macronutrient status (Table 1).

\section{Placement of Table 1}




\section{ACCEPTED MANUSCRIPT}

To produce Kemi block type high carbohydrate (HC), starch $(200 \mathrm{~g})$ was dissolved in water (1000ml) in a metal container and put to boil while stirring continuously to prevent the emergence of lumps. After heating to $150^{\circ} \mathrm{C}$, fat $(10 \mathrm{~g})$ was added to the homogenous mixture by dropping cubes a $2 \mathrm{~g}$ cube a time until the cubes have liquefied and dissolved. Once all the fat had been added, casein (100g) was also added with ongoing stirring. The mixture was then left on heat for a further 10 minutes to bring everything to boil. The mixtures were transferred in to a Kenwood food processor and mixed at full speed for 1 minute. This process was repeated four times with scrapping of splashed product back into bulk to ensure a homogenous product. From this homogenous product, $80 \mathrm{~g}$ portions were transferred into individual sterile plastic containers and stored at different temperatures $-15,-5$ and $+5^{\circ} \mathrm{C}$ for 10 hours prior to irradiation treatment. The same production process detailed above, the exception being differing quantities of starch, casein, fat and water were used in producing the remaining types of Kemi block namely; low carbohydrate (LC), high protein (HP), low protein (LP), high fat (HF) and low fat (LF).

\subsection{Gamma irradiation treatment}

The products were transported to Synergy Health - now part of Steris irradiation facility, Swindon, UK, in a Waeco Cool Freeze CF50 mobile refrigeration unit. At the irradiation facility, the six different compositions were randomly placed inside a polystyrene box $(590 \times$ $365 \times 155 \mathrm{~mm}$ ) (Figure 1), to minimise loss of temperature during the radiation treatment. Alanine pellets dosimeters by Aerial, France, were placed inside six of the containers at the top and the bottom as illustrated in Figure 2, to measure the received dose. Several considerations were reflected upon, for example the best location to position the dosimeters to determine the minimum and maximum area of received dose. The decision to position the dosimeters at the four corners/angles of the packaging (Figure 1), was taken based on the closeness to the radiation rays. In addition to these four dosimeters, a further two dosimeters 


\section{ACCEPTED MANUSCRIPT}

were placed at the centre of the packaging which was considered based on a suitable distance from the packaging wall. This positioning, is to justify and enumerate dose measurement at different angles. Samples were also randomly placed (Table 2a, b and c) in the box to maximise the dose received. Each box was then irradiated at different intended doses $(1,3,5$ and $10 \mathrm{kGy})$. After irradiation, the products were removed from the polystyrene boxes and placed inside the mobile refrigeration unit at $4 \pm 1{ }^{\circ} \mathrm{C}$ before being transported to the Royal Agricultural University, Cirencester, UK for analysis. The dose acquired by the samples was also assessed by determining the absorbance of alanine pellets dosimeters to the different levels of radiation.

For the purpose of the treatment, Kemi block was divided into five groups based on radiation intensity: Group 1 (control, 0kGy), Group 2 (1kGy), Group 3 (3kGy), Group 4 (5kGy) and Group 5 (10kGy) with 30 samples (6 compositions x 5 replicates) per group.

\section{Placement of Figure 1}

\section{Placement of Table 2a, $b$ and $c$}

\section{Placement of Figure 2}

The products were irradiated with different target doses $(1,3,5,10 \mathrm{kGy})$ using an irradiator with ${ }^{60}$ Cobalt source and at a dose rate of $2 \mathrm{kGyhr}^{-1}$. After the irradiation treatment, samples were stored under refrigeration at $4 \pm 1^{\circ} \mathrm{C}$, and subjected to periodic analysis at 7 days interval. During the irradiation treatment, effort were made to ensure samples held at $5^{\circ} \mathrm{C}$ preirradiation do not suffer from excessive temperature increase which could affect the intended microbial and shelf-life analysis. This objective was achieved by putting the samples in a polystyrene boxes supported by ice parks to minimise temperature increase especially for the 10kGy dose which was in the chamber for 5 hours. 


\section{ACCEPTED MANUSCRIPT}

\subsection{Chemical Analysis}

The proximate analysis (protein, moisture and fat) of all types of Kemi block samples were determined according to the AOAC methods of analysis (AOAC, 2005). All samples were analysed in duplicate before and after irradiation.

\subsubsection{Moisture content}

Moisture contents were determined by placing $5 \mathrm{~g}$ of sample in an oven at $100^{\circ} \mathrm{C} \pm 1$ for 4 hours or until a constant weight is achieved (IDF-ISO-AOAC method).

$\%$ Moisture $=\frac{M \text { Initial }-M \text { Dried }}{M \text { Initial }} \times 100$

\subsubsection{Fat content}

The fat content was analysed according to the Babcock method of analysis. Kemi block sample was minced to small particles. From the minced particles, $9 \mathrm{~g}$ was weighed into a Paley bottle and $10 \mathrm{ml}$ deionised water added at $60^{\circ} \mathrm{C}$. To the mixture, $17.5 \mathrm{ml}$ of sulphuric acid was added in four increments. After the sulphuric acid addition, the entire content was mixed until it is of even brown colour and all kemi block particles dissolved. The Paley bottle was placed inside a centrifuge for 5 minutes. After 5minutes of centrifuging, the content was topped up with deionised water at $60^{\circ} \mathrm{C}$ enough to bring the content to within one-quarter inch of base of neck. The content was put back in a centrifuge for 2 minutes. At the lapse of the 2 minutes centrifugation period, deionised water at $60^{\circ} \mathrm{C}$ was added to help float fat into the neck of bottle. The bottle was then centrifuge for additional 1 minute. At the end of the centrifuge, the bottle was tempered in a water bath at $55^{\circ} \mathrm{C}$ for 5 minutes. Four drops of glymol was added to the fat column and measured. The length of the fat from the demarcation between fat and glymol to the bottom of the lower meniscus was measured. Fat which is described as the mass fraction of substances was expressed as a percentage by mass. 


\section{ACCEPTED MANUSCRIPT}

\subsubsection{Protein content}

The crude protein content $(N \times 6.38)$ of the sample was determined according to Kjeldahl method (IDF-ISO-AOAC method).The digestion of Kemi block sample was carried out using a block - digestion apparatus, with a mixture of concentrated sulfuric acid and potassium sulfate while adding copper (II) sulfate as a catalyst for the conversion of organic nitrogen present to ammonia. The resulting ammonia is then distilled using steam distillation with an excess of boric acid solution titrated with hydrochloric acid solution. The amount of nitrogen expressed as percentage by mass is then calculated from the amount of ammonia produced and multiplied by 6.38 which is the protein conversion factor for dairy products.

\subsubsection{Ash content}

Ash is defined as the residue remaining after ignition at $550^{\circ} \mathrm{C}$ to constant weight (approximately 5 hours). The ignition at $550^{\circ} \mathrm{C}$ aids the elimination of all organic matter available, with the remaining material being predominantly minerals.

$\%$ Ash $=\frac{\text { weight of residue }}{\text { weight of sample }} \times 100$

\subsubsection{Carbohydrate}

The total carbohydrate content was estimated by subtracting the addition of moisture, protein, fat and ash content from a value of 100 .

Total carbohydrates $=100-(g$ moisture $+g$ protein $+g$ fat $+g$ ash $)$

\subsection{6 $\mathrm{pH}$ measurement}

The $\mathrm{pH}$ content of Kemi block sample was determined by aseptically transferring $5 \mathrm{~g}$ of Kemi block into a sterile stomacher bag and homogenised with $20 \mathrm{ml}$ deionised water in a stomacher lab blender -80 (Seward, UK). The $\mathrm{pH}$ of the homogenate was measured using a digital pH meter (PHB-213 microprocessor pH meter, Omega). 


\section{ACCEPTED MANUSCRIPT}

\subsection{Microbial analysis}

After the irradiation treatment, the samples were transported back to the laboratory for further analysis to check the sterility. Before every analysis, each of the sample containers was disinfected with $70 \%$ ethanol. After disinfecting the containers, to reduce the incidence of cross-contamination, $5 \mathrm{~g}$ of Kemi block were taken aseptically and transferred into a sterile stomacher bag with $45 \mathrm{ml}$ of sterilised maximum recovery diluent (MRD) and homogenised for $120 \mathrm{~s}$ in a stomacher lab blender - 80 (Seward Medical, London, UK). Dilutions $\left(10^{-1}\right.$ to $10^{-4}$ ) of the sample homogenate were prepared in MRD diluents and spread on duplicate growth plates to estimate microbial counts.

\subsubsection{Total viable counts}

The colony forming units (CFU) for total viable counts (TVC), were enumerated by plating on Plate Count Agar medium (PCA) (Oxoid), and incubated aerobically at $32 \pm 2^{\circ} \mathrm{C}$ for 48 \pm 3 hours (AOAC, 2005). Subsequently, plates exhibiting 30-300 colonies were counted after the incubation period. The TVC is deduced by multiplying the counted colonies with the dilution factor and expressed as the number of CFU per grams of samples according to ISO (1995). The means and standard deviation were subsequently calculated.

\subsection{Statistical analysis}

In order to determine the radiation effect, on the shelf-life of the six varieties of Kemi block samples, all the analysis were carried out in duplicate. The data, were subjected to an analysis of variance (ANOVA), using the IBM SPSS statistics 22 software, to determine any significance and the differences among means $(\mathrm{p} \leq 0.05)$ were compared using Tukey multiple comparison treatment means. Mean values and the standard deviations (SD) were reported. 


\section{ACCEPTED MANUSCRIPT}

\subsection{Dosimetry}

Alanine pellets dosimeter, is an alanine substrate pressed into pellet shape with wax for binding material. The pellets, are placed into a film package with a barcode for identification. Upon completion of the irradiation treatment, the alanine pellets dosimeters which were irradiated together with Kemi block samples to measure the absorbed dose, were removed from the samples and inserted into an Electron paramagnetic resonance (EPR) spectrometer. The spectrometer, automatically transfers the barcode and takes the readings to calculate the reproducible measurable response to radiation as the absorbed dose. Dose mapping, which is important in radiation technology, is performed by determining the most efficient means of placing product in a carrier or tote and placing numerous dosimeters throughout the product load to establish the minimum and maximum areas of received dose. In the context of this research, Table 3, shows the result for the anticipated dose, the averaged absorbed dose, and the respective time taken to attain the dose.

\section{Placement of Table 3}

\section{Results and discussion}

In the discussion, we will review the physicochemical and microbiological properties with reference to shelf-life while evaluating the impact of the radiation treatment on each parameters.

\subsection{Effect of processing time on the product temperature}

The samples held at $5^{\circ} \mathrm{C}$ prior to irradiation were closely monitored to ensure products were not thermally abused due to the increase in temperature while in the irradiation chamber, it is worth noting that the temperature inside the irradiation chamber was around $18^{\circ} \mathrm{C}$. To minimise the impact of the chamber temperature, samples were placed inside a polystyrene boxes and irradiated alongside some ice packs, $85 \%$ of the $5^{\circ} \mathrm{C}$ samples maintained their initial temperature with exceptions of few which recorded a temperature increase of $7^{\circ} \mathrm{C}$ and 


\section{ACCEPTED MANUSCRIPT}

$8^{\circ} \mathrm{C}$. On the other hand, the frozen samples $\left(-5^{\circ} \mathrm{C}\right.$ and $\left.-15^{\circ} \mathrm{C}\right)$ did not exceed the posttreatment storing temperature of $+4{ }^{\circ} \mathrm{C}$.

\subsection{Physicochemical analysis}

Physicochemical parameters (moisture, fat, protein, $\mathrm{pH}$, and ash) of Kemi block both irradiated and non-irradiated, were measured immediately following irradiation, and over storage period at $4 \pm 1^{\circ} \mathrm{C}$, at 7 day interval subsequently. According to the analysis of the irradiated and non-irradiated samples, moisture content ranged between 54.4 and $85.1 \%$, protein ranged between 1.7 and 29.8\%, fat ranged between 1.7 and $29.7 \%$, while pH ranged between 5.69 and 7.44. An overall analysis of these parameters showed no significant difference $(P \geq 0.05)$, between both the irradiated and non-irradiated samples for all the characteristics measured. The findings concurred with the findings of earlier studies on actual dairy products - soft whey cheese (Tsiotsias et al., 2002), Feta cheese (Konteles et al., 2009), and Ras cheese (Shalaby et al., 2016), whereby no difference was observed in the physicochemical parameters of these cheeses at different irradiated doses.

\subsubsection{Radiation effects on the Physicochemical Properties}

The physicochemical measures of both the control and irradiated samples of Kemi block exhibited no significant difference $(P \geq 0.05)$ on the first day of analysis. However, over the storage period, Kemi block irradiated at a higher doses showed significant reduction in the moisture content $(P \leq 0.05)$ of some of the varieties. Furthermore, the observed reduction was found to be proportional to both the irradiation dose and the storage time. The recorded loss in the moisture content, could be due to the decrease in the water-holding capacity of casein as reported by Shalaby et al., (2016). This reduction is also proportional to both the irradiation dose and the length of the storage time. Considering the applied methodology, the obtained results might, at best, indicate that the nitrogen content had not changed. However, 


\section{ACCEPTED MANUSCRIPT}

any consideration regarding the maintenance of protein content and quality is purely speculative. This shows that neither the irradiation process nor the storage time affect the protein content of the products. Previous studies by Ham et al., (2009), on the quality of plain yogurt irradiated at 1, 3, 5 and 10kGy found no difference in the protein content and total solids of the yogurt evaluated further aligning with our findings.

The ability of the samples displaying no significant differences in most measures justifies the practicability of irradiation in the production of wholesome food without causing undesirable changes to the chemical properties of food products. It would seem that the effectiveness of a radiation dose depends both on the external factors like presence or absence of oxygen, moisture content, density, temperature in combination with the food composition (Odueke et $a l ., 2016)$. Irradiation and heat, are the only two identified methods of obviating microorganisms in food, while other methods may inhibit their growth. Irradiation and heat utilises the energy absorption effects leading to cell membrane or DNA damages. The above points demonstrate the importance of wet conditions in the efficacy of thermos radiation. Also, irradiation used in combination with other treatment presents a synergistic effect in decreasing the microbial load and the dose required to inhibit pathogenic bacteria. This synergistic effect also encompasses reducing the rate of unsaturated fatty acid oxidation (Lacroix and Quattara, 2000; Kumar et al., 2013).

\subsection{Microbiological analysis}

The microbial count of the control and irradiated samples of Kemi block at irradiated doses of $1,3,5$ and $10 \mathrm{kGy}$ stored at $4 \pm 1^{\circ} \mathrm{C}$ are shown in Table $4 \mathrm{a}$ and $4 \mathrm{~b}$. While samples irradiated at a $1 \mathrm{kGy}$ dose exhibit some reduction in the TVC readings compared to the control, however, these reduction were found to be statistically insignificant. But statistical evaluation of the samples irradiated at 3,5 and $10 \mathrm{kGy}$ dose displayed significant reduction in the total viable count. The reduction percentage in the TVC of Kemi block (HC) on the first day of 


\section{ACCEPTED MANUSCRIPT}

analysis was about $33 \%$ at a $1 \mathrm{kGy}$ dose and $100 \%$ at higher doses within the irradiated samples.

\section{Placement of Table 4a}

\section{Placement of Table $4 b$}

\subsubsection{Radiation effects on the microbial load / shelf-life}

The present study took a different approach to what was available in the literature by not carrying out sensory evaluation and also not inoculating microorganisms. Instead, the study was designed to investigate the irradiation effects on the natural microbiota of Kemi block, hence, there was no inoculation of microorganisms into the samples to simulate the natural food chain. The justification to avoid inoculation of microorganisms was due to, available literatures reporting on the success of radiation technology in reducing inoculated microorganisms significantly (Tsiotsias et al., 2002; Konteles et al., 2009; Kim et al., 2010). The study also omits any sensory study based on available literature evidence supporting sensory acceptability (Shalaby et al., 2016) when carried out under the right conditions, and with the right dose.

The issue of food safety is a crucial subject in achieving food sustainability. However, the shelf-life of food products are often compromised by the presence of wide diversity of spoilage and pathogenic bacteria. The results of the microbial analysis of the irradiated Kemi block samples, exhibited a lower $(P \leq 0.05)$ bacteria load over the refrigerated storage days than the non-irradiated samples (control). This finding broadly correlates with the results of earlier studies relating to the efficacy of radiation technology in reducing microbial loads (Tsiotsias et al., 2002; Jo et al., 2007; Kim et al., 2007a; Kim et al., 2008; Konteles et al., 2009 and Kim et al., 2010). The graph representing the effects of different radiation dose and refrigerated storage on the TVC of the six varieties of Kemi block were presented in Figure 3 -8 below. 


\section{ACCEPTED MANUSCRIPT}

\section{Placement of Figure 3}

\section{Placement of Figure 4}

\section{Placement of Figure 5}

\section{Placement of Figure 6}

\section{Placement of Figure 7}

\section{Placement of Figure 8}

The benchmark for the shelf-life analysis was established at $20000 \mathrm{CFU} / \mathrm{g}$ (Wehr and Frank, 2004) which was the legal standard for pasteurised milk. Hence, this study only enumerates the total microbial load without identifying the type of microorganisms present. This is because the aim of the study was to investigate the viability of radiation in enhancing food safety. Therefore, identification is beyond the scope of the study.

According to our result, the TVC count presented in Table $4 \mathrm{a}$ and $4 \mathrm{~b}$, the shelf-life estimation of the non-irradiated Kemi block was deduced to be in region of between 14 and 35 days as presented in Figure 3 - 8. This difference observed in the estimated shelf-life is based on the composition and pre-treatment storage condition. The trend in the compositional and storage effects on the shelf-life of the sample could also be seen in the table presented.

On the first day of analysis, the average initial TVC analysis on Kemi block stored at $-15^{\circ} \mathrm{C}$ and $+5^{\circ} \mathrm{C}$ pre-irradiation, showed the following log value readings; $\mathrm{HC}$ (2.67 and 2.60), LC (2.62 and 2.85), HF (2.70 and 2.80), LF (2.70 and 2.71), HP (2.78 and 2.93), and LP (2.79 and 2.90) respectively. However, results on day 14 showed the product irradiated at higher doses (5 and 10) exhibiting no growth, while some of the control samples were already at the end of shelf-life. This result demonstrated the sterilising effect of gamma irradiation. Corresponding with our results, were the earlier studies by Tsiotsias et al., (2002), on soft whey cheese (Anthotyros). They reported the success of gamma irradiation at 2 and $4 \mathrm{kGy}$ in reducing the microbial load by approximately $1-2 \log$ cycles. Furthermore, they concluded 


\section{ACCEPTED MANUSCRIPT}

that irradiation dose of up to $4 \mathrm{kGy}$ could be employed in the control of Listeria monocytogenes.

These reports substantiate our results of $1 \mathrm{kGy}$ dose being observed to extend the shelf-life of the Kemi block by a further 7 to 14 days in some samples when compared with the control sample. Several investigations into the enhancement of microbial quality of dairy products by gamma irradiation without compromising the nutrition and organoleptic properties have been reported by; Hashishaka et al., (1989); Bougle and Stahl, (1994); Ennahar et al., (1994); Bandekar et al., (1998); Kamat et al., (2000); Aly et al., (2012); Badr (2012).

Kim et al., (2007b) reported the absence of viable cells at 5kGy dose demonstrating that irradiating up to $5 \mathrm{kGy}$ may substantially improve the safety of chocolate ice cream. This investigation correlates with our result of no viable cells in samples treated at 5kGy until analysis day 35 .

Based on the microflora of the irradiated samples, it can be concluded that low dose irradiation has a selective effect on the natural microflora of Kemi block judging by the behaviour of the surviving microflora which varies as described by Farkas (1989), on the food nature and associated microorganisms. The observed difference in the TVC of the samples may be due to the compositional attributes (i.e. fat, protein and carbohydrate content) of the products since the radio-sensitivity of bacteria varies with the medium in which irradiation occurs which according to Urbain (1989), the optimum conditions occurred in medium of high water activity $\left(\mathrm{A}_{\mathrm{w}}>0.95\right)$, including lack of competitive radiochemical or chemical activity from solid particles.

\section{Conclusion}

From our findings, it is now possible to report based on the results of investigations into the safety of dairy-like product treated with gamma irradiation, this study confirmed that gamma 


\section{ACCEPTED MANUSCRIPT}

irradiation treatment extends the shelf-life of pseudo-dairy products stored at $4 \pm 1^{\circ} \mathrm{C}$. Our findings do not include identifying the specific species of the microorganism group present. However, in evaluating the dose range examined in this study, we can propose that the higher the irradiation dose, the lower the microbial load resulting in the production of high quality, shelf-stable food products. Likewise, irradiated Kemi block showed a bacteriological quality corresponding to a high quality product thereby validating the effectiveness of these radiation doses in this particular product from the bacteriological perspective. Hence, our findings further add to the growing body of research that indicates, irradiation together with good manufacturing practices is crucial in ensuring food safety. Future studies, will be focusing on the practicality of radiation technology in the provision of, wholesome dairy products with an enhanced shelf-life.

\section{Acknowledgement}

The Authors would like to thank Synergy health Plc, Swindon, UK now part of Steris for providing the use of the radiation facility. 


\section{ACCEPTED MANUSCRIPT}

\section{Reference}

1. Adeil Pietranera, M.S., Narvaiz, P., Horak, C., and Kairiyama, E. (2003). Irradiated ice creams for immunosuppressed patients. Radiation Physics and Chemistry. 66: $357-365$.

2. AOAC. (2005). Official methods of analysis (18th Ed.). Arlington: Association of Official Analytical Chemists.

3. Aly, S. A; Farag, D. E and Galal, E. (2012). Effect of Gamma Irradiation on the Quality and Safety of Egyptian Karish Cheese. Journal of American Science. 8(10): $761-766$.

4. Badr, H. M. (2012).Improving the Microbial Safety of Ice Cream by Gamma Irradiation. Food and Public Health. 2(2): 40-49.

5. Bandekar, J., Kamat, A., and Thomas, P. (1998). Microbiological quality of the dairy product pedha and its improvement using gamma irradiation. Journal of Food Safety. 18(3): $221-230$.

6. Blank, G., Shamsuzzaman, K., and Sohal, S. (1992). Use of electron beam irradiation for mold decontamination of cheddar cheese. Journal of Dairy Science. 75: 13 - 20.

7. Bougle, D. L., and Stahl, V. (1994). Survival of Listeria monocytogenes after irradiation treatment of camembert cheeses made from raw milk. Journal of Food Protection. 57(9): $811-813$.

8. Burditt, A. K. (1994). Irradiation. In: Quarantine treatments for pests of food plants, pp. 101-117. Sharp, J. L., and Hallman, G. J., (Eds). Westview Press, Boulder, Colorado.

9. Crawford, L.M., and Ruff, E.H. (1996). A review of the safety of cold pasteurization through irradiation. Food Control. 7: 87 - 97.

10. Diehl, J. F. (1995). Safety of irradiated foods. New York, Marcel Dekker. 


\section{ACCEPTED MANUSCRIPT}

11. EFSA. (2011). Scientific Opinion on the Chemical Safety of Irradiation of Food. EFSA Panel on Food Contact Materials, Enzymes, Flavourings and Processing Aids (CEF). EFSA Journal. 9(4):1930. 1 - 57.

12. Ennahar, S., Kuntz, F., Strasser, A., Bergaentzle, M., Hasselmann, C., and Stahl, V. (1994). Elimination of Listeria monocytogenes in soft and red smear cheese by irradiation with low energy electrons. International Journal of Food science and Technology. 29(4): $395-403$.

13. Farag, K. W., Lyng, J. G., Morgan, D. J., Cronin, D. A. (2011). A comparison of conventionally and radio frequency thawing of beef meats: effects on product temperature distribution. Food Bioprocess and Technology 4 (7) 1128-1136.

14. Farag, K.W., Lyng, J. G., Morgan, D. J., Cronin, D. A. (2008). A comparison of conventionally and radio frequency tempering of beef meats: effects on product temperature distribution. Meat Science 80 (2) 488-495.

15. Farkas, J. (1989). Microbiological safety of irradiated foods. International Journal of Food Microbiology. 9:1-15.

16. Hallman, G. J. (2001).Irradiation as a Quarantine Treatment. In: Food irradiation: Principles and Applications, pp.113 - 130. Molins, R. A., Ed. John Wiley \& Sons, Inc.

17. Ham, J. S., Jeong, S. G., Lee, S. G., Han, G. S., Jang, A., Yoo, Y. M., Chae, H. S., Kim, D. H., Kim, H. J., Lee, W. K., and Jo, C. (2009). Quality of irradiated plain yogurt during storage at different temperatures. Asian-Australasian Journal of Animal Sciences. 22(2): 289-295.

18. Hashisaka, A. E., Weagant, S. D., and Dong, F. M. (1989). Survival of Listeriamonocytogenes in mozzarella cheese and ice-cream exposed to gamma irradiation. Journal of Food Protection. 52(7): 490-492. 


\section{ACCEPTED MANUSCRIPT}

19. Huo, J. X., Bai, C. Y., Guo, L. H., \& Zhao, Z. (2013). Effect of electron beam irradiation on the shelf life of mozzarella cheese. International Journal of Dairy Technology. 66(3): 352-358.

20. Institute of Food Science and Technology (IFST). (2015). Food Irradiation. Available online: http://www.ifst.org/print/118 (accessed on 09/02/2016).

21. ISO (International Organisation for Standardization) (1995) ISO/TC-34/SC.6. Recommendation of the meeting of the ISO of meat and meat products. The Netherlands, 10-18.

22. Jo, C., Kim, H.J., Kim, D.H., Lee, W.K., Ham, J.S., and Byun, M.W. (2007). Radio sensitivity of selected pathogens in ice cream. Food Control. 18: 859-865.

23. Kamat, A., Warke, R., Kamat, M., and Thomas, P. (2000). Low-dose irradiation as a measure to improve microbial quality of ice cream. International Journal of Food Microbiology. 62(1-2): 27-35.

24. Khattak, K.F., and Rahman, T.U. (2016). Effect of gamma irradiation on the vitamins, phytochemicals, antimicrobials, and antioxidant properties of Ziziphus mauritiana Lam. Leaves. Radiation Physics and Chemistry. 127: 243 - 248.

25. Kilcast, D. (1994). Effect of irradiation on vitamins. Food Chemistry. 49(2): 157-164.

26. Kim, H. J., Song, B. S., Kim, J. H., Choi, J., Lee, J. W., Jo, C., and Byun, M.W. (2007a). Application of gamma irradiation for the microbiological safety of sliced cheddar cheese. Journal of Radiation Industry.1: 15 - 19.

27. Kim, H. J., Song, B. S., Kim, J. H., Choi, J., Lee, J. W., Jo, C., and Byun, M.W. (2007b). Development of ice cream with improved microbiological safety and acceptable organoleptic quality using irradiation. Journal of Animal Science and Technology. 49: 515 - 522 . 


\section{ACCEPTED MANUSCRIPT}

28. Kim, H.J., Song, H.P., Ham, J.S., Lee, J.W., Kim, K., and Jo, C. (2008). Effect of gamma irradiation on the overall quality of a commercial plain-type yogurt product. Korean Journal for Food Science of Animal Resources. 28: 574 - 579.

29. Kim, H. J., Ham, J. S., Lee, J. W., Kim, K., Ha, S. D., and Jo, C. (2010). Effects of gamma and electron beam irradiation on the survival of pathogens inoculated into sliced and pizza cheeses. Radiation Physics and Chemistry. 79: 731 - 734.

30. Komolprasert, V. (2007). Packaging for foods treated with ionizing radiation. In Packaging for Non-Thermal Processing of Food, $1^{\text {st }}$ ed., Han, J.H. Ed., Blackwell Publishing Ltd, Ames, IA,USA, pp. 87 - 117.

31. Konteles, S., Sinanoglou, V.J., Batrinou, A., and Sflomos, K. (2009). Effects of y irradiation on Listeria monocytogenes population, colour, texture and sensory properties of Feta cheese during cold storage. Food Microbiology, 26(2): 157 - 165.

32. Kumar, R., Johnsy, G., Rajamanickam, R., Lakshmana, J.H., Kathiravan, T., Nataraju, S., and Nadanasabapathi. S. (2013). Effect of gamma irradiation and retort processing on microbial, chemical and sensory quality of ready- to -eat (RTE) chicken pulav. International Food Research journal. 20(4):1579 - 1584.

33. Kume, T., Furuta, M., Todoriki, S., Uenoyama, N., and Kobayashi Y. (2009). Status of food irradiation in the world. Radiation Physics and Chemistry, 78: 222-226.

34. Lacroix, M., and Follett, P. (2015). Combination irradiation treatments for food safety and phytosanitary uses. Stewart Postharvest Review. 11: 1 - 10.

35. Lacroix, M., and Quattara, B. (2000). Combined industrial processes with irradiation to assure innocuity and preservation of food products - a review. Food Research International. 33: $719-724$.

36. Lalaguna, F. (2003). Physicochemical response of Palmita-type cheese to low dose irradiation. Journal of Food Science. 68(1): 26 - 30. 


\section{ACCEPTED MANUSCRIPT}

37. Lee Sun-Young (2004). Irradiation as a method for decontaminating food. Internet Journal of Food Safety. 3:32-35.

38. Mahapatra, A. K., Muthukumarappan, K., and Julson, J. L. (2005). Applications of ozone, bacteriocins and irradiation in food processing: A review. Critical Reviews in Food Science and Nutrition. 45(6): 447 - 462.

39. Maherani, B., Hossain, F., Criado, P., Ben-Fadhel, Y., Salmieri, S., and Lacroix, M. (2016). World Market Development and Consumer Acceptance of Irradiation Technology. Foods. 5(4): 79.

40. McClements, J. M. J., Patterson, M. F and Linton, M. (2001). The effects of growth stage and growth temperature on high hydrostatic pressure inactivation of some psychrotrophic bacteria in milk. Journal of Food Protection. 64 (4): 514-522.

41. Odueke,O. B., Farag, K. W., Baines, B. N. and Chadd S. A. (2016). Irradiation Applications in Dairy Products: a Review. Food and Bioprocess Technology. 9(5):751 $-767$.

42. Ortega-Rivas, E. (2007). Processing effects for safety and quality in some nonpredominant food technologies. Critical Reviews in Food Science and Nutrition. 47: 161-173.

43. Pryke, D. C., and Taylor, R. R. (1995). The use of irradiated food for immunosuppressed hospital patients in the United Kingdom. Human Nutrition and Dietetics. 8: 411 - 416.

44. San Martin, M. F., Barbosa-Canovas, G. V., and Swanson, B. G. (2002). Food processing by high hydrostatic pressure. Critical Reviews in Food Science and Nutrition. 42: 627-645. 


\section{ACCEPTED MANUSCRIPT}

45. Shalaby, A. R., Anwar, M. M., Sallam, E. M and Emam, W. H. (2016). Quality and safety of irradiated food regarding biogenic amines: Ras cheese. International journal of Food Science and Technology. 51: 1048 - 1054.

46. Tsiotsias, A., Savvaidis, I., Vaassila, A., Kontominas, M., and Kotzekidou, P. (2002). Control of Listeria monocytogenes by low-dose irradiation in combination with refrigeration in the soft whey cheese 'Anthotyros'. Food Microbiology. 19:117 - 126.

47. Urbain, W. M. (1989). Food irradiation: the past fifty years as prologue to tomorrow. Food Technology. 43: 6-92.

48. Wehr, H.M., and Frank, J.F. (2004). Standard Methods for the Evaluation of Dairy Products. APHA, Washington. 570pp. (SMEDP, $17^{\text {th }}$ ed.).

49. WHO. (1992). Report of the Panel on Food and Agriculture, WHO Commission of Health and Environment. World Health Organisation, Geneva.

50. Yun, H., Lee, K.H., Lee, H.J., Lee, W.J., Ahn, U.D., and Jo, C. (2012). Effects of high-dose irradiation on quality characteristics of ready-to-eat chicken breast. Radiation Physics and Chemistry. 81: 1107 - 1110.

51. Zink, D. L. (1997). The impact of consumer demands and trends on food processing. Emerging Infectious Diseases. 3: 467 - 469. 


\section{ACCEPTED MANUSCRIPT}

Figures

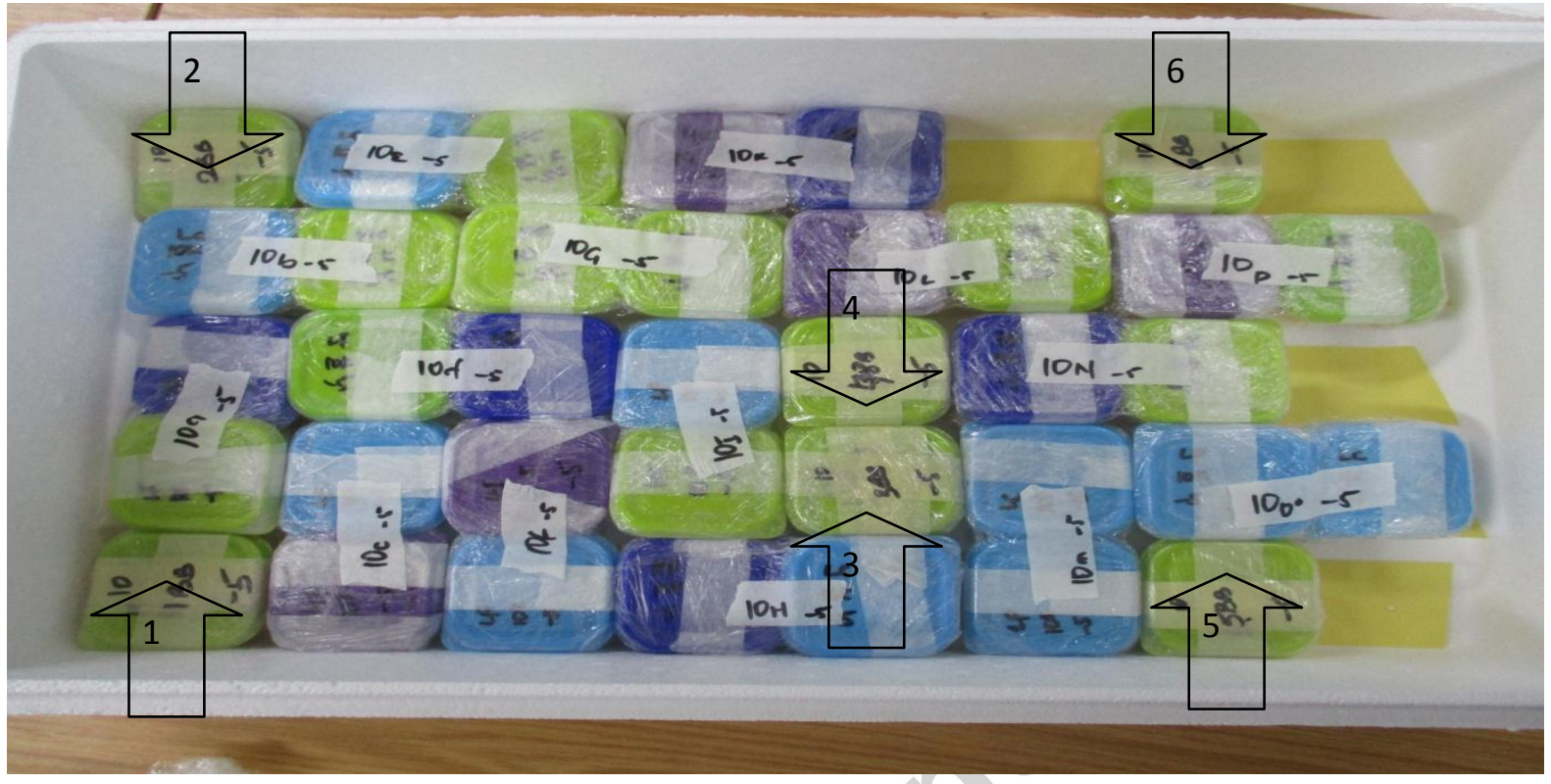

Figure 1: Kemi block positioning with arrows showing dosimeters position during irradiation treatment 


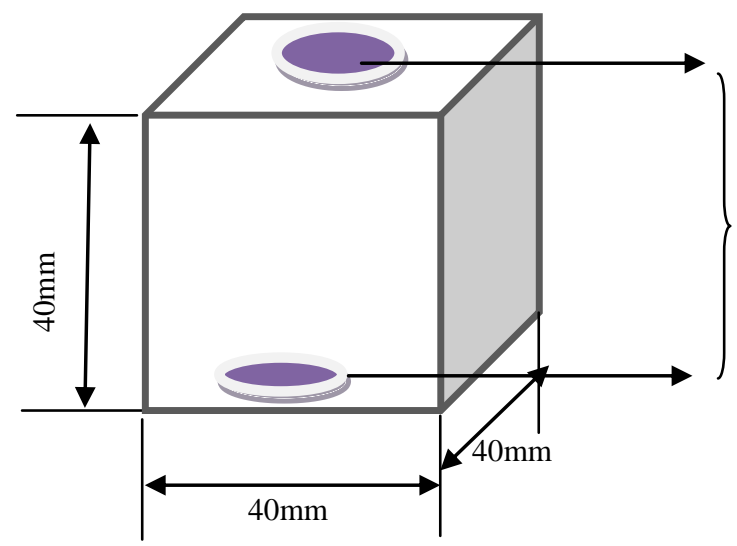

Alanine pellet dosimeter

Figure 2: Graphic representation of Kemi block dimensions and position of dosimeter 


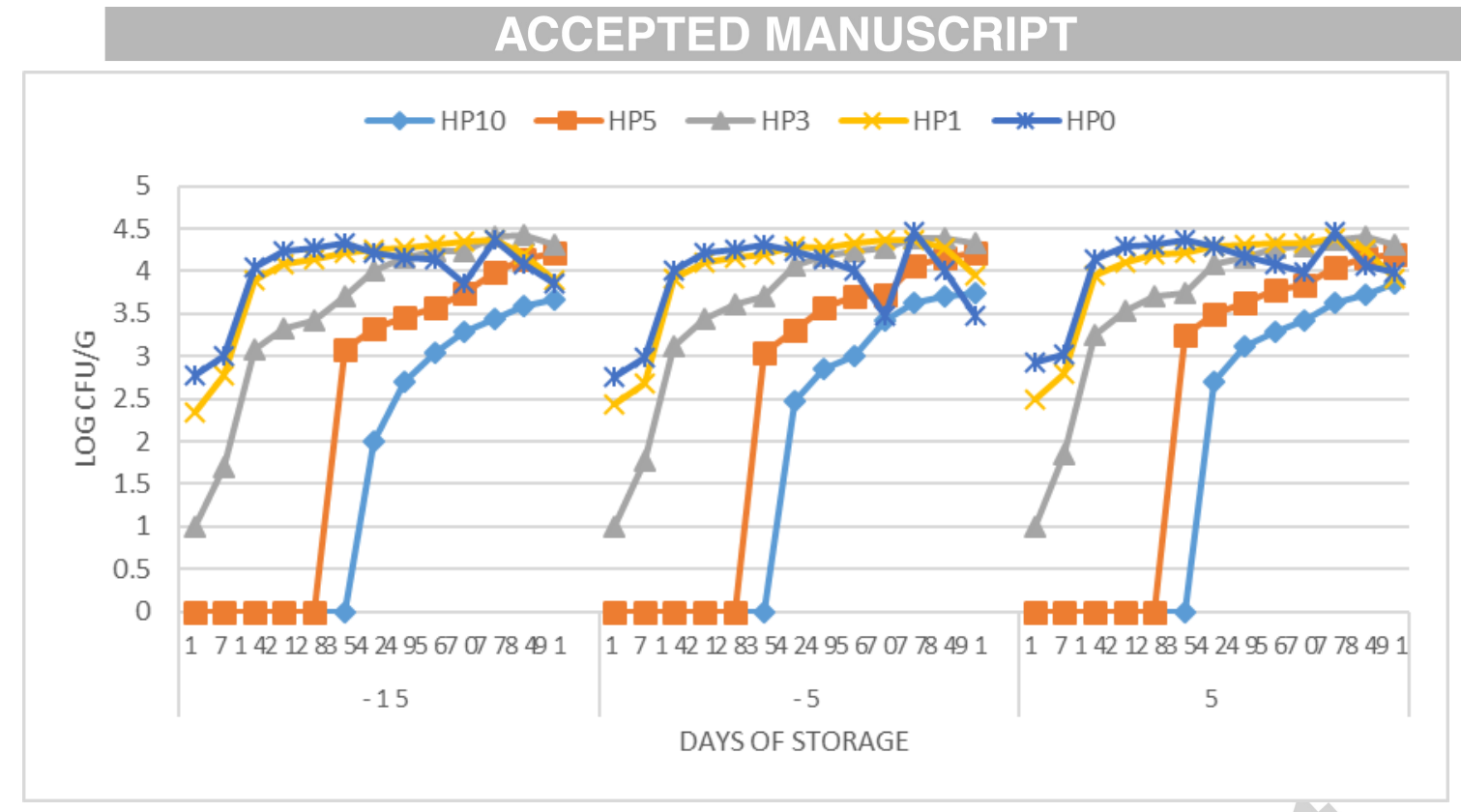

Figure 3: Counts (mean $\pm \mathrm{SD}, \mathrm{n}=3$ ) of total viable count in the high protein (HP) composition of Kemi block as affected by different radiation dose, pre- irradiation temperature $(5,-5$ and $15^{\circ} \mathrm{C}$ ), and refrigeration storage at $4 \pm 1^{\circ} \mathrm{C}$ 


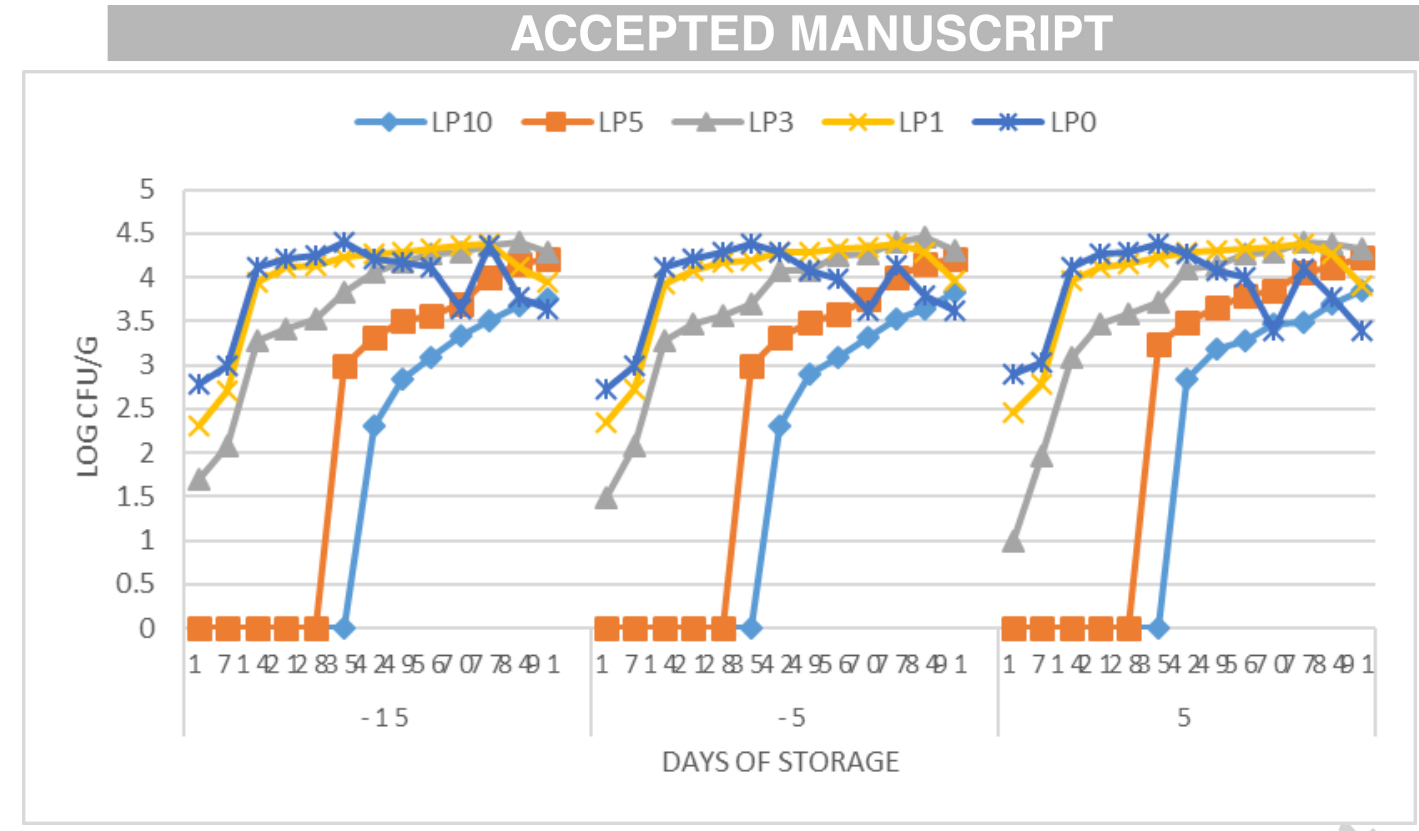

Figure 4: Counts (mean $\pm \mathrm{SD}, \mathrm{n}=3$ ) of total viable count in the low protein (LP) composition of Kemi block as affected by different radiation dose, pre- irradiation temperature $(5,-5$ and $\left.15^{\circ} \mathrm{C}\right)$ and refrigeration storage at $\pm$ $1^{\circ} \mathrm{C}$ 


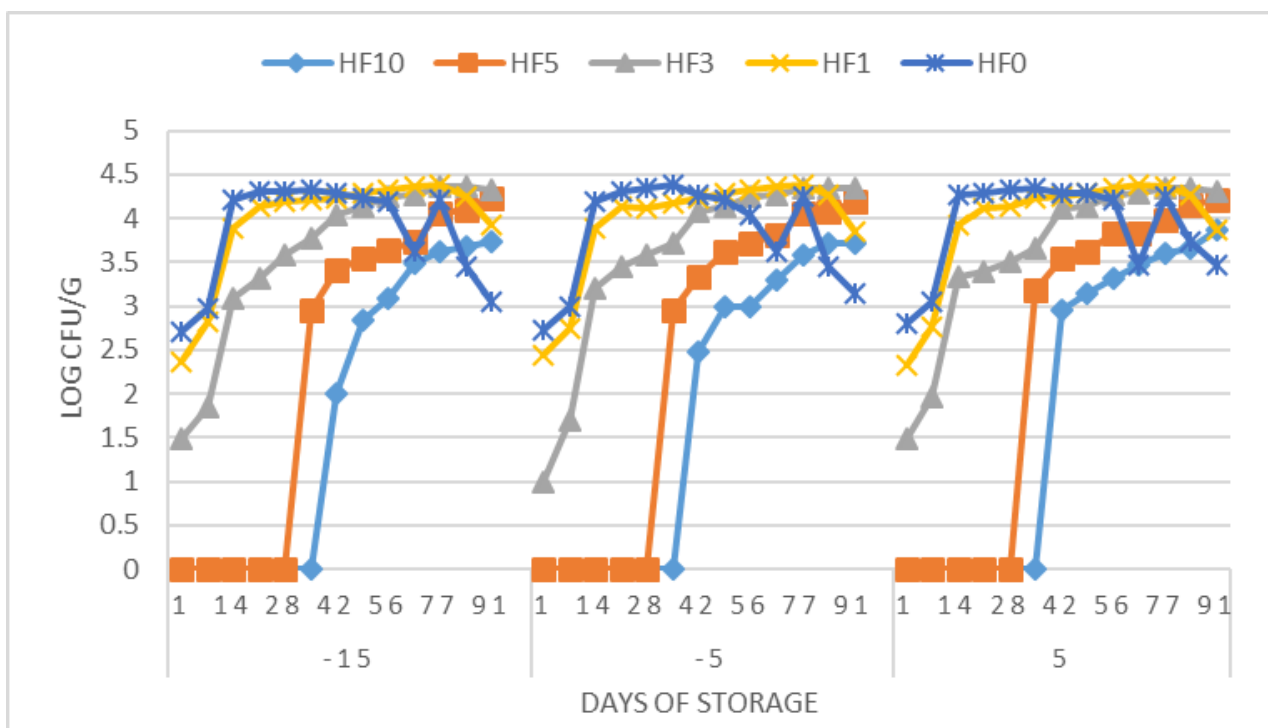

Figure 5: Counts (mean $\pm \mathrm{SD}, \mathrm{n}=3$ ) of total viable count in the high fat (HF) composition of Kemi block as affected by different radiation dose, pre- irradiation temperature $(5,-5$ and $15^{\circ} \mathrm{C}$ ), and refrigeration storage at $4 \pm 1{ }^{\circ} \mathrm{C}$ 


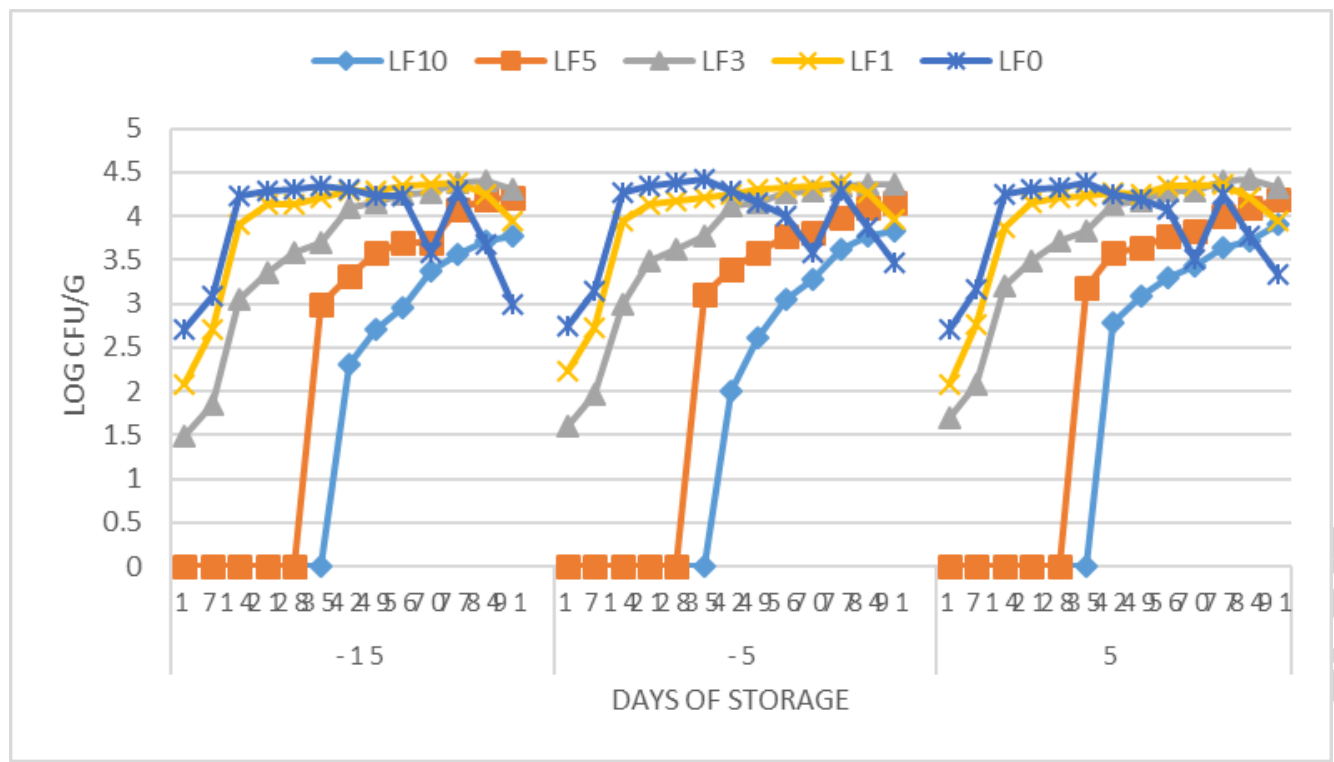

Figure 6: Counts (mean $\pm \mathrm{SD}, \mathrm{n}=3$ ) of total viable count in the low fat (LF) composition of Kemi block as affected by different radiation dose, pre- irradiation temperature $(5,-5$ and $15^{\circ} \mathrm{C}$ ), and refrigeration storage at $4 \pm 1^{\circ} \mathrm{C}$ 


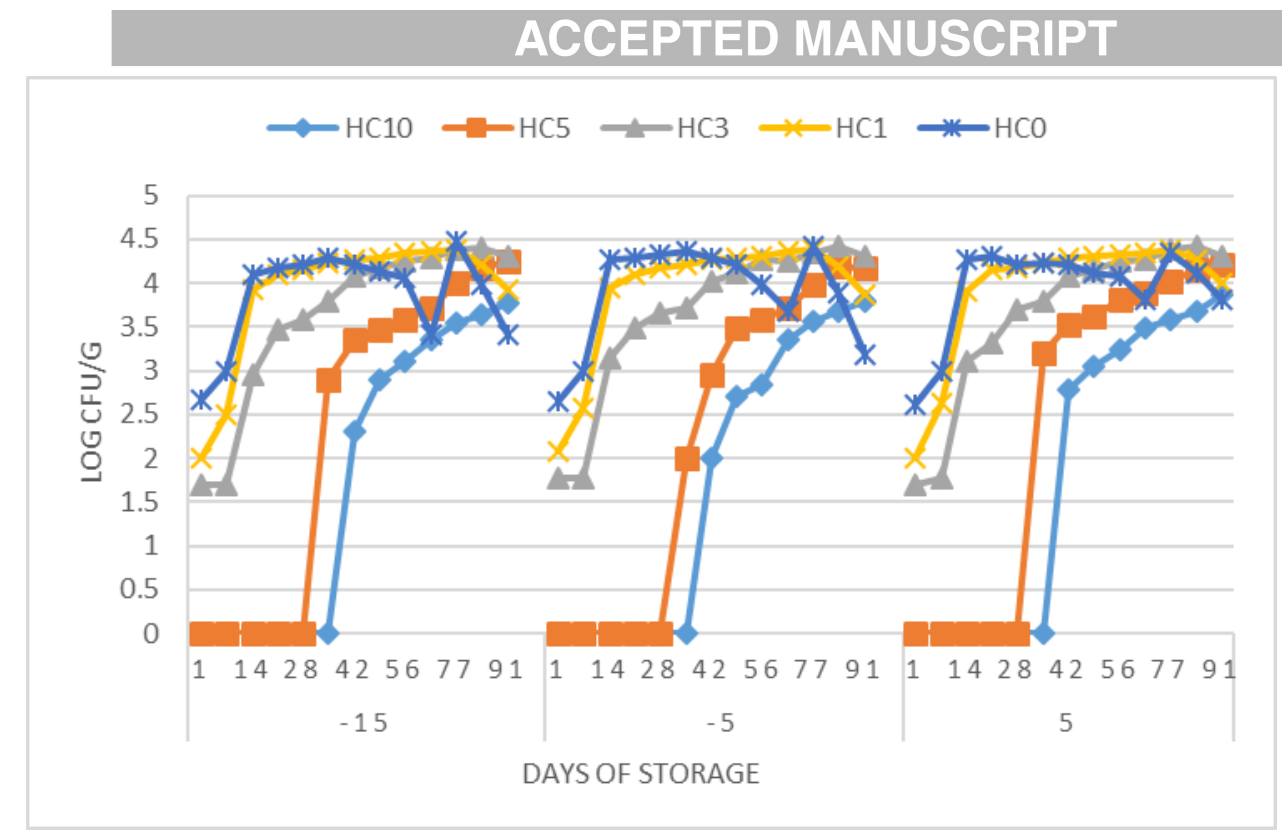

Figure 7: Counts (mean $\pm \mathrm{SD}, \mathrm{n}=3$ ) of total viable count in the high carbohydrate $(\mathrm{HC})$ composition of Kemi block as affected by different radiation dose, pre- irradiation temperature $\left(5,-5\right.$ and $\left.-15^{\circ} \mathrm{C}\right)$, and refrigeration storage at $4 \pm 1{ }^{\circ} \mathrm{C}$ 


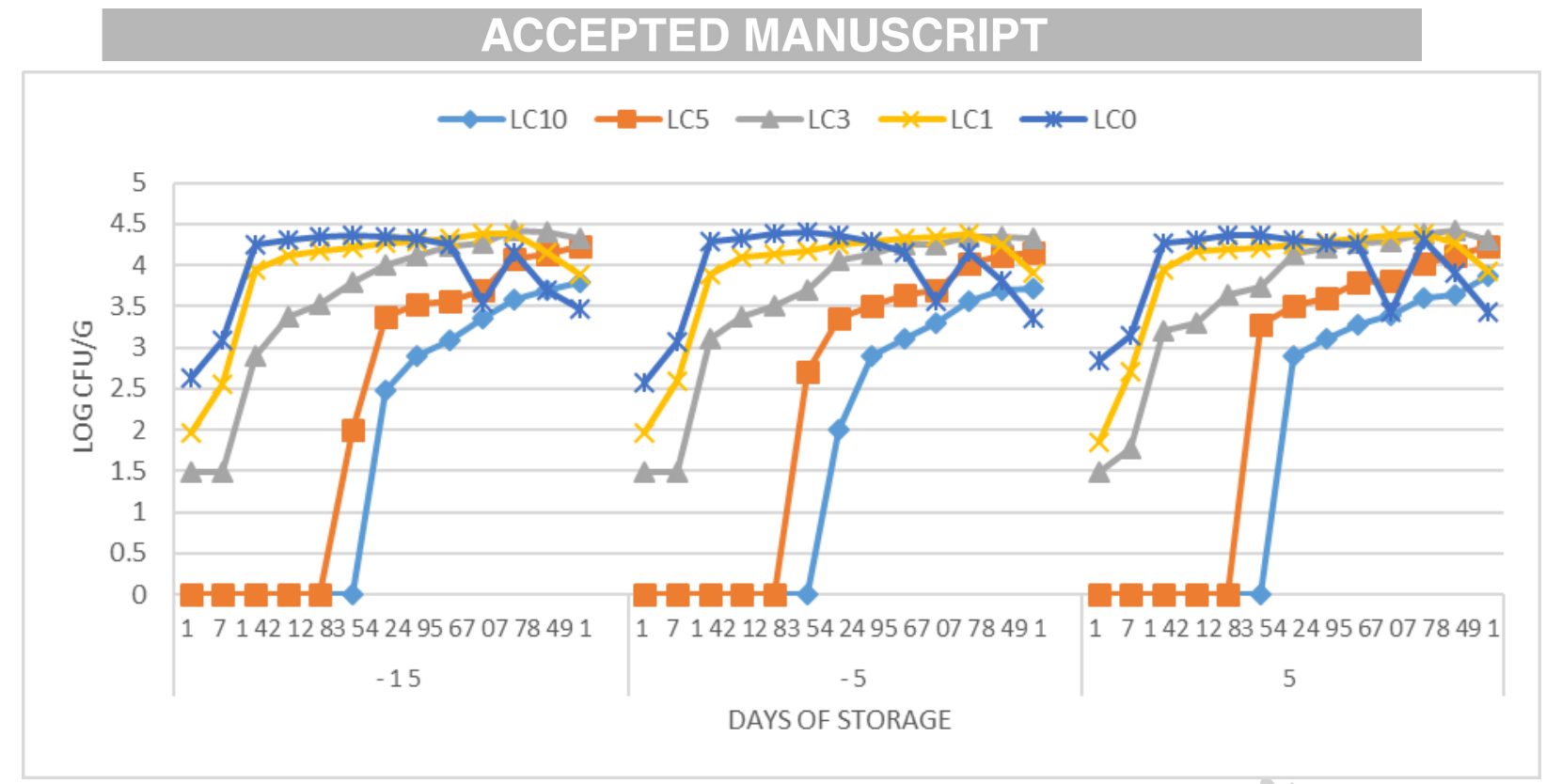

Figure 8: Counts (mean $\pm \mathrm{SD}, \mathrm{n}=3$ ) of total viable count in the low carbohydrate (LC) composition of Kemi block as affected by different radiation dose, pre- irradiation temperature $\left(5,-5\right.$ and $\left.-15^{\circ} \mathrm{C}\right)$, and refrigeration storage at $4 \pm 1{ }^{\circ} \mathrm{C}$ 
Tables

Table 1: Composition of the Kemi blocks

\begin{tabular}{lccccc}
\hline Kemi Block Type & \multicolumn{7}{l}{ Protein (\%) Fat $(\%)$ Carbohydrate (\%) Moisture (\%) } & Simulated food \\
\hline High Protein (HP) & 21.8 & 2.7 & 2.7 & 72.7 & Cheddar Cheese \\
Low Protein (LP) & 2.9 & 12.9 & 12.9 & 71.4 & Clotted cream \\
High Carbohydrate (HC) & 1.7 & 1.7 & 13.3 & 83.3 & Mozzarella cheese \\
Low Carbohydrate (LC) & 15.0 & 15.0 & 3.3 & 66.7 & Greek yogurt \\
High Fat (HF) & 7.4 & 29.6 & 7.4 & 55.6 & Hard cheese \\
Low Fat (FT) & 11.3 & 2.5 & 11.3 & 75.0 & Cottage cheese \\
\hline
\end{tabular}


Table2 a, b, c: Tabular representation of randomly placed Kemi block and dosimeter position at $5^{\circ} \mathrm{C},-5^{\circ} \mathrm{C}$ and $-15^{\circ} \mathrm{C}$

a

\begin{tabular}{llllll}
\hline $\mathrm{D}_{1}$ & $\mathrm{HF}$ & $\mathrm{HC}$ & $\mathrm{HP}$ & $\mathrm{LC}$ & $\mathrm{D} 2$
\end{tabular}

LP LF HF HC HP LC

LF LP LC HF HC HP

LC LF D3 D4 LP HC

LP LC LF HP HC HF

D5 $\quad$ LF $\quad$ HP $\quad$ LP $\quad$ HF $\quad$ D6 $\mathrm{b}$

\begin{tabular}{llllll}
\hline D1 & LP & HF & HC & LF & D2
\end{tabular}

LC HP LP HF HC LF

HP LC LF LP HF HC

LF $\quad$ HP $\quad$ D3 D4 LC HF

LC LF HP HC HF LP

D5 HP HC LC LP D6

\begin{tabular}{llllll}
\multicolumn{9}{c}{$c$} & & & \\
\hline D1 & HC & LC & LP & HP & D2
\end{tabular}

LF HF HC LC LP HP HF LF HP HC LC LP HP HF D3 D4 LF LC LF HP HF LP LC HC D5 HF LP LF HC D6 


\section{ACCEPTED MANUSCRIPT}

Table 3: Predicted and average actual received radiation dose at $5^{\circ} \mathrm{C},-5^{\circ} \mathrm{C}$ and $-15^{\circ} \mathrm{C}$

\begin{tabular}{|c|c|c|c|c|}
\hline \multirow[b]{2}{*}{$\begin{array}{l}\text { Anticipated dose } \\
(\mathrm{kGy})\end{array}$} & 5 & -5 & -15 & \multirow[b]{2}{*}{$\begin{array}{l}\text { Duration } \\
\text { (mins) }\end{array}$} \\
\hline & $\begin{array}{l}\text { Absorbed dose } \\
(\mathrm{kGy})\end{array}$ & $\begin{array}{l}\text { Absorbed dose } \\
(\mathrm{kGy})\end{array}$ & $\begin{array}{l}\text { Absorbed dose } \\
(\mathrm{kGy})\end{array}$ & \\
\hline 1 & $0.94 \pm 0.02$ & $0.95 \pm 0.04$ & $0.90 \pm 0.57$ & 30 \\
\hline 3 & $2.36 \pm 0.07$ & $2.42 \pm 0.14$ & $2.44 \pm 0.12$ & 90 \\
\hline 5 & $3.70 \pm 0.10$ & $3.74 \pm 0.18$ & $3.77 \pm 0.24$ & 150 \\
\hline 10 & $7.81 \pm 0.58$ & $7.90 \pm 0.38$ & $8.00 \pm 0.91$ & 300 \\
\hline
\end{tabular}


Table 4a: TVC (log cfu/g) of Kemi block as affected by gamma irradiation dose and storage periods at $-15^{\circ} \mathrm{C}$

\begin{tabular}{|c|c|c|c|c|c|c|}
\hline \multirow[t]{2}{*}{ Composition } & \multirow{2}{*}{$\begin{array}{l}\text { Storage } \\
\text { Days }\end{array}$} & \multicolumn{4}{|c|}{ Irradiation dose $(\mathrm{kGy})$ at $-15^{\circ} \mathrm{C}$} & \multirow[b]{2}{*}{10} \\
\hline & & 0 & 1 & 3 & 5 & \\
\hline $\mathrm{HC}$ & $\begin{array}{l}1 \\
35 \\
42 \\
56 \\
91\end{array}$ & $\begin{array}{l}2.67 \\
4.28 \\
4.21 \\
4.05 \\
3.41\end{array}$ & $\begin{array}{l}2.00 \\
4.22 \\
4.27 \\
4.34 \\
3.92\end{array}$ & $\begin{array}{l}1.70 \\
3.80 \\
4.08 \\
4.26 \\
4.31\end{array}$ & $\begin{array}{l}\mathrm{NC} \\
2.90 \\
3.36 \\
3.59 \\
4.24\end{array}$ & $\begin{array}{l}\mathrm{NC} \\
\mathrm{NC} \\
2.30 \\
3.11 \\
3.77\end{array}$ \\
\hline $\mathrm{LC}$ & $\begin{array}{l}1 \\
21 \\
42 \\
70 \\
91\end{array}$ & $\begin{array}{l}2.63 \\
4.31 \\
4.35 \\
3.54 \\
3.46\end{array}$ & $\begin{array}{l}1.95 \\
4.11 \\
4.27 \\
4.37 \\
3.88\end{array}$ & $\begin{array}{l}1.48 \\
3.38 \\
4.01 \\
4.27 \\
4.32\end{array}$ & $\begin{array}{l}\mathrm{NC} \\
\mathrm{NC} \\
3.38 \\
3.70 \\
4.22\end{array}$ & $\begin{array}{l}\mathrm{NC} \\
\mathrm{NC} \\
2.48 \\
3.36 \\
3.79\end{array}$ \\
\hline $\mathrm{HF}$ & $\begin{array}{l}1 \\
21 \\
49 \\
56 \\
91\end{array}$ & $\begin{array}{l}2.70 \\
4.30 \\
4.24 \\
4.19 \\
3.04\end{array}$ & $\begin{array}{l}2.36 \\
4.14 \\
4.29 \\
4.33 \\
3.92\end{array}$ & $\begin{array}{l}1.48 \\
3.32 \\
4.14 \\
4.25 \\
4.33\end{array}$ & $\begin{array}{l}\mathrm{NC} \\
\mathrm{NC} \\
3.54 \\
3.63 \\
4.24\end{array}$ & $\begin{array}{l}\mathrm{NC} \\
\mathrm{NC} \\
2.85 \\
3.08 \\
3.74\end{array}$ \\
\hline LF & $\begin{array}{l}1 \\
21 \\
42 \\
56 \\
91\end{array}$ & $\begin{array}{l}2.70 \\
4.29 \\
4.30 \\
4.22 \\
3.00\end{array}$ & $\begin{array}{l}2.08 \\
4.13 \\
4.29 \\
4.34 \\
3.93\end{array}$ & $\begin{array}{l}1.48 \\
3.36 \\
4.09 \\
4.26 \\
4.31\end{array}$ & $\begin{array}{l}\mathrm{NC} \\
\mathrm{NC} \\
3.32 \\
3.69 \\
4.21\end{array}$ & $\begin{array}{l}\mathrm{NC} \\
\mathrm{NC} \\
2.30 \\
2.95 \\
3.77\end{array}$ \\
\hline HP & $\begin{array}{l}1 \\
28 \\
42 \\
70 \\
91\end{array}$ & $\begin{array}{l}2.78 \\
4.27 \\
4.21 \\
3.85 \\
3.85\end{array}$ & $\begin{array}{l}2.34 \\
4.14 \\
4.25 \\
4.35 \\
3.89\end{array}$ & $\begin{array}{l}1.00 \\
3.41 \\
4.01 \\
4.24 \\
4.30\end{array}$ & $\begin{array}{l}\mathrm{NC} \\
\mathrm{NC} \\
3.32 \\
3.75 \\
4.22\end{array}$ & $\begin{array}{l}\mathrm{NC} \\
\mathrm{NC} \\
2.00 \\
3.28 \\
3.67\end{array}$ \\
\hline LP & $\begin{array}{l}1 \\
28 \\
42 \\
70 \\
91\end{array}$ & $\begin{array}{l}2.79 \\
4.25 \\
4.21 \\
3.64 \\
3.64\end{array}$ & $\begin{array}{l}2.30 \\
4.14 \\
4.27 \\
4.36 \\
3.93\end{array}$ & $\begin{array}{l}1.70 \\
3.52 \\
4.05 \\
4.29 \\
4.29\end{array}$ & $\begin{array}{l}\mathrm{NC} \\
\mathrm{NC} \\
3.32 \\
3.69 \\
4.20\end{array}$ & $\begin{array}{l}\mathrm{NC} \\
\mathrm{NC} \\
2.30 \\
3.34 \\
3.75\end{array}$ \\
\hline
\end{tabular}


Table 4b: TVC (log cfu/g) of Kemi block as affected by gamma irradiation dose and storage periods at $5^{\circ} \mathrm{C}$

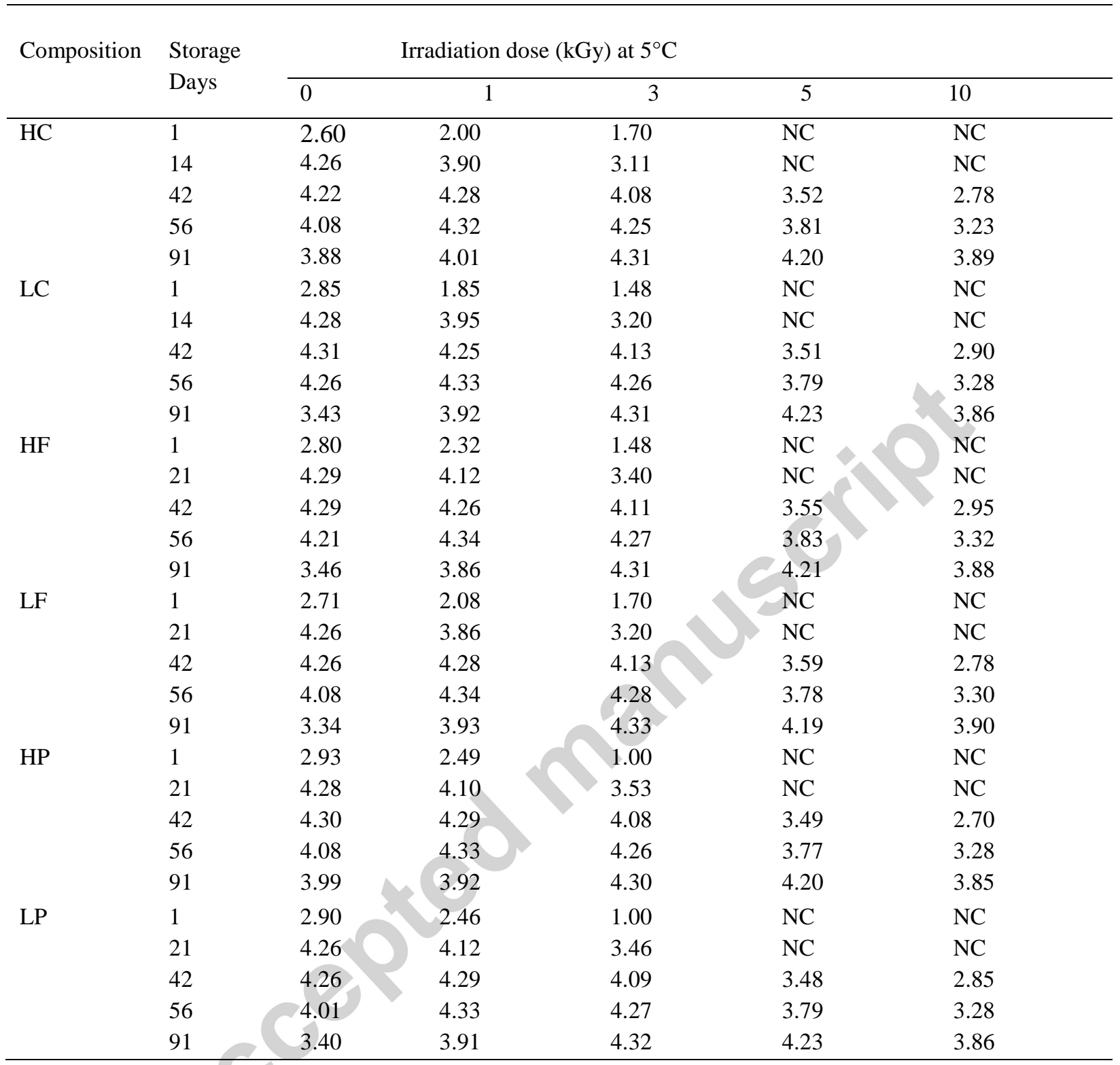

\section{Highlights}

- The efficacy of radiation treatment was investigated.

- Gamma irradiation treatment increases the shelf-life of food product.

- Gamma irradiation did not induce any significant change in the physicochemical properties of the product. 